\title{
Megadose Methyl-Prednisolone (MDMP) for Autoimmune Hemolytic Anemia
}

\section{Otoimmün Hemolitik Anemi Tedavisinde Megadoz Metilprednizolon (MDMP)}

\author{
Şinasi Özsoylu \\ Fatih University, School of Medicine, Department of Hematology, Ankara, Turkey
}

To the Editor,

Üsküdar Teke and colleagues originally used $1 \mathrm{mg} \mathrm{kg}-1$ day $^{-1}$ methylprednisolone (MDMP) for their patient with autoimmune hemolytic anemia without improvement, and after 3 weeks of steroid treatment splenic infarct developed. The patient was splenectomized but the hemolytic anemia again did not improve. Therefore, azathioprine was prescribed [1].

A 36-year-old woman with severe autoimmune hemolytic anemia was sent to me from the Netherlands, who was treated for more than 1.5 years with corticosteroid. Her anemia and hemolysis responded promptly to MDMP administration without disappearance of Coombs positivity [2].

The authors searched for causes of thrombophilia in their patient because of splenic infarct, without evaluation of the fibrinolytic system.

Since the coagulation depends on the dynamic balance between procoagulant and fibrinolytic activities, the later system should also be evaluated in the case of splenic infarct, I believe.

On this occasion, I would like to bring to attention that high homocysteine levels' relation to thrombosis is doubtful, as was previously studied [3].

Address for Correspondence: Sinasi ÖZSOYLU, M.D.,

Fatih University, School of Medicine, Department of Hematology, Ankara, Turkey

Phone: +90 3122354188 E-mail: sinasiozsoylu@hotmail.com

Received/Geliș tarihi : February 12, 2013

Accepted/Kabul tarihi : February 13, 2013

\section{References}

1 Teke HU, Karahan S, Gumus U. Splenic infarct in a patient with autoimmune hemolytic anemia. Turk J Hematol. 2012;29:432-433

2. Özsoylu Ş, Berencshot H. Megadose prednisolone (MDMP) for a patient with autoimmune hemolytic anemia (AIHA) resistant to conventional corticostoroid administration. (Accepted for publication by TJH)

3. Özsoylu Ş. Is a high homosystein level related to thrombosis? TJH 2012;29:438.

\section{Reply}

We want to thank for the comments of Şinasi ÖZSOYLU, MD. The new diagnosis in primary (idiopathic) autoimmune hemolytic anemia patients is suggested as glucocorticoids (steroids), prednison $1 \mathrm{mg} / \mathrm{kg} /$ day or metilprednisolon intravenously. With this dosage it is recommended to continue the treatment until the target hemoglobin value $>10 \mathrm{~g} / \mathrm{dl}$ and hematocrit value $>30 \%$ are reached and if the target values are not reached within 3 weeks, second step of treatment should be applied [1]. In our case after 3 weeks steroid treatment, both symptomatic splenic infarct development and due to no result of 3 weeks steroid treatment splenectomy is applied simultaneously as a second step treatment. In our case due to splenic infarct development in accordance with etiology trombophilia investigation are 
observed [2]. As Dr. Özsoylu has already specified, due to the coagulation being dependant on the dynamic balance between procoagulant and fibrinolytic activity, fibrinolytic system could have been evaluated as well. However, because of the insufficient laboratory conditions, investigation about the fibrinolytic system couldn't have been done.

\section{Hava Üsküdar Teke1, Samet Karahan²}

${ }^{1}$ Eskişehir Osmangazi University, Faculty of Medicine, Department of Hematology, Eskişehir, Turkey

${ }^{2}$ Kayseri Education and Research Hospital, Depertmant of Internal Medicine, Kayseri, Turkey

\section{References}

1. Lechner K, Jager U. How I treat autoimmune hemolytic anemias in adults. Blood 2010;116:1831-1838.

2. Teke HÜ, Karahan S, Gümüş Ü. Splenic infarct in a patient with autoimmune hemolytic anemia. Turk J Hematol 2012;29:432-433. 